\title{
Issues in separating Chairman and CEO/MD roles in Family Firms: Evidence from India's SEBI reform
}

\author{
Guragain, Laxmi Narayan \\ Ph.D. student, Graduate School of Regional Policy Design,
}

Hosei University, Tokyo, Japan.

\begin{abstract}
This paper analyzes the issues of implementing the new corporate governance code Securities and Exchange Board of India (SEBI), which is Contract agreement reforms (Clause 49) enacted in 2018.This code has ordered Indian companies to separate the role of chairman and chief executive officer (CEO)/managing director (MD) in family firms. Not only that more severe penalties were introduced in 2020 to expand the efficacy of this enactment, the SEBI had also recommended certain companies, in the new contract agreement reform, to implement it by October 01, 2019.

There exist many problems on implementation of this reform in India. The separation between the position of Chairman and CEO/MD, which may lead to more independent boards, will provide the essential checks and balances over management's performances. But, in most Indian promoter-led companies, the posts of chairman and CEO/MD are interwoven. The promoters say that the committee did not recommend that the two posts be separated, and hope the order gets deferred for 2-3 years.

A qualitative research analysis is conducted focusing on the implications of this reform on family businesses and their managing boards. Hence, this paper will analyze the present conditions, trends, and future challenges from a theoretical as well as practical perspective.
\end{abstract}

Keywords: Family firms, corporate governance reforms, separated Chairman and CEO/MD, SEBI, India.

\section{INTRODUCTION}

Family firms are organizations owned or actively managed by more than one member of the same family[3]. Family-owned firms are essential factors in the growth and internationalization of emerging economies [1]. Family firms are the most dominant among publically traded firms across the world [33], [6], [2], [20].

The growth of Asian family firms, for example, across international boundaries, has drawn attention to their leaders, who need to isolate their domestic markets from the international business by being aware that the global economy is susceptible to influences from the ongoing developments in this region[8], [35]. Family dominate many developing economies with about two-thirds of the family firms in Asian countries run and control by families or individuals [9].Statistically, the family-owned companies in the Asian region account for 
$85 \%$ of the private sector's economy [19], [23], [25]. In India, over $60 \%$ of the reported top 500 firms are family-owned firms[7], [35]. The research reveals that in the continental Europe, about $44 \%$ of publicly held firms are family-controlled [14]. In the USA, the ownership concentration is moderated; among the Fortune 500 firms, about one-third is family firms[2].

For a number of decades, there has been a significant surge in studies of family firms, including those focusing mainly on Asian family-owned companies [13], [25], [32]. Referencing the business insider, the writer, Core Stern, presents the CS global data and explains that 64 percent of 920 largest family-owned firms in the world are from emerging Asia [10].Some of these family-owned firms are top-ranked among the largest companies in a world such as Reliance Industries (India), Samsung Electronics (South Korea), and Chow Tai Fook (Hong Kong) [35].

Codes of various countries give broader responsibilities to the Chairman, such as engaging shareholders in more business deals, ensuring the effectiveness of the Board in helping businesses maintain consumer friendly business, and understanding the companys' financial position as well as strategic plans for sustainable businesses. Furthermore, the corporate governance codes internationally prescribe bifurcation of the role of the chief executive officer (CEO)/Managing director(MD) and the role of Chairman. The Chairman is expected to provide leadership to the board of directors, and is responsible for the board's composition and should focus on the long-term vision rather than day-to-day activities. The Chairman is expected to make sure that the board sets and implements the strategy effectively. A CEO/MD should focus on running the company's business on a day-to-day basis. The CEO/MD handles the company's strategic plans and daily operations with the corporate objectives set by the board. It also provides leadership to the company. So, considering the aforementioned statistics, views, and international experiences, this paper will assess both the structural and economic issues that are seen or will be seen on family-owned businesses in India due to the 2019 reforms to Clause 49, particularly concerning the requirement for a separate chairman and CEO/MD in Indian family-own companies.

\section{LITERATURE REVIEW}

As majority of the family firms in India are owned and controlled by a specific single family, a member of that family or a founder, if a company is owned and run by a single person, wants to hold an influential position in that particular firm. The positions such as chairman, CEO, and executive director of the company are considered influential in that company's positional hierarchy [30]. However, an excellent Corporate Governance principle expects that there should be an apparent splitting of responsibilities at the helm of the company, which should secure a balance of power and authority so that no single individual has unfettered rights of the decision in a board. Therefore, the decision to merge the two distinct posts of chairman and CEO/MD into one should be publicly justified [18].

The SEBI was formed in 1992. Until the mid-1990s, the Indian economy was growing steadily. So, the Indian firms began to seek capital from a variety of sources to finance the expansion of their businesses into the business spaces created in the global market by liberalization and the growth of outsourcing [27]. After the SEBI 
was formed, many researchers were focused on studying the significance of the clause 49 listing agreements, such as corporate governance reforms because most reforms had affected all the then listed Indian firms. That is because the SEBI has introduced a rigorous regulatory regime to ensure fairness, transparency, and good practice. For example, for greater transparency, the SEBI has mandated disclosure of all transactions where the total quantity of shares is over $0.5 \%$ of the company's equity[7].

Indian government's adaptation of the significant corporate governance reforms (Clause 49) in 2000 required family-owned companies to have audit committees, a minimum number of independent directors, and $\mathrm{CEO} / \mathrm{CFO}$ as their certified internal controlling agencies. This suggests that properly designed mandatory corporate governance reforms can increase India's share prices and company's values rather than the silent topmost management reforms as described previously during the establishment of the SEBI [5]. Sen [31] noted that although SEBI had issued various guidelines for improving India's corporate governance norms, many companies had not yet disclosed their several essential issues. Not only the non-mandatory but also many mandatory requirements have not been yet disclosed by the companies.

\section{Objectives of the Study}

This paper analyzes a new rule by Securities and Exchange Board of India (SEBI). SEBI has mandated and recommended all the listed family firms to implement the rule by October, 01 2019. SEBI wants listed family firms to voluntarily consider separating the posts of their chairman and CEO/MD as a good governance practice.

Since the 1990s various reforms have been undertaken to improve corporate governance in India So, the central focus of this study is to analyze the significant issues in Board Structure, and Chairman and COE/MD separated India's Family Firms associated with corporate governance in India. Keeping these issues in mind, the following objectives were framed.

R.Q. 1 Issues and Problems in Role Duality of Chairman and CEO/MD roles in Indian Family firms.

R.Q.2 Provide a lesson based on international practices on the importance of Separated Chairman and $\mathrm{CEO} / \mathrm{MD}$ roles in Corporate Governance performance.

R.Q. 3 Suggestion for improvement of effective Board structure.

\section{Research Methodology and Data Collection}

This study has relied upon the secondary data and literature review available in the public domain. For collecting secondary data, various journals, research papers, working papers, published reports and data available in the public domain were referred. The conclusion and suggestions were drawn based on available information. Since it is qualitative, no quantitative tools have been used for analysis. As the study was carried based on secondary data and available literature, the conclusions drawn are purely based on the available information. 


\section{ANALYSIS}

\section{Background and Reforms of Corporate Governance in India}

The principle of corporate governance is a set of relationships between a company's management and board, and its shareholders and other stakeholders [26]. In India, many high-profile corporate governance scams including the stock market scam (1992), the UTI scam (1997), the Ketan Parekh scam (2001), and the Satyam scam (2008) led the shareholders of respective companies to criticize the role of their chairman or CEO/MD, and thus, appealed for a need to make transparent corporate governance in India as it considerably affects the development of the country. The Companies Act of 2013 introduced some progressive and transparent processes, which benefit stakeholders, directors, and the promoter or management of companies. Investment advisory services and proxy firms provide insufficient information to the shareholders about these newly introduced processes and regulations, which aim to develop corporate governance in India [36].

Since the 1990s, various reforms were undertaken to improve corporate governance in India, the most important event being the establishment of the SEBI in 1992. After the SEBI was established, four major committees (Bajaj Committee in 1996, Birla Committee in 2000, Chandra Committee in 2002, and Narayanan Murthy Committee in 2003) were formed to review corporate governance issues, and to recommend governance laws and reforms. Furthermore, corporate governance issues in India may be compounded by the nature of corporate ownership, where family-run businesses dominate the ownership structure.

As cited by Thapar and \& Sharma [36], Corporate governance was guided by Clause 49 of the Listing Agreement, before the Companies Act of 2013 was introduced. According to the new provision, SEBI has also approved certain amendments in the Listing Agreement to enhance the transparency in transactions of listed companies, and to give a more significant privilege to minority stakeholders in influencing to the decisions of management.

\section{SEBI clause (49)}

In 1992, the SEBI was established with a mandate to protect investors, and to improvetheir transparency and securities in a market and thereby, led it to beestablished as an autonomous regulatory body for security regulations of those investors [22]. In a significant step towards codifying the corporate governance code, SEBI enshrined clause 49 in the Stock Listing Agreement (2000), which has now become the standard for corporate governance in India. The basic standard underlying the entire listing agreement based is corporate governance. Currently, listing agreements have 54 clauses; all of them are based on this concept. Also, there is a clause 49, which explicitly deals with corporate governance. The word, listing, as mentioned above, means the approval of a security regulatory to trade on a recognized stock exchange.

According to Dave et al.[11], the clause 49 of the listing agreement with SEBI, states that every company that comes under the deal will have to implement the requirements laid down by SEBI under this clause 49. These requirements are as follows:

(1) Composition \& size of Board 
(2) Board meeting and attendance

(3) Chairman and CEO duality

(4) Audit committee

(5) Shareholder/Investors Grievance Committee

(6) Remuneration Committee

(7) Disclosures (mandatory)

(8) Non-Mandatory requirements

(9) $\mathrm{CEO}$ and CFO certificate

(10) Corporate Governance Report

The Indian corporate governance in practice was considered weak and quite dysfunctional. This situation formed the background to the promulgation of the Clause 49 of the stock exchange listing agreement in 2000 by the SEBI[12]. The SEBI correctly implemented the corporate governance reforms and recommendations advocated bythese (Bajaj, Birla, Chandra, Narayanan Murthy and Kotak) committees, for example, through the legislation of Clause 49 of the Listing Agreements. The Clause 49 reforms include increasing the number of outside directors, dealing with post duality as well as the existence of financial expertise in directors. There has also been a change to the Clause 49 of the Listing Agreement by the SEBI in 2005 requiring a minimum number of outside directors on board of directors. But, the SEBI Clause 49 of the Listing Agreement remains silent about the separation of a with Chairman and a CEO/MD into two positions. The figure below presents the timeline of the Clause 49 reforms.

Table 1: A Timeline of Clause 49 Reforms

\begin{tabular}{|c|c|c|c|}
\hline OCT.,1999 & FEB.,2000 & MARCH,2003 & MARCH,2006 \\
\hline $\begin{array}{l}\text { Kumar Mangalam Birla } \\
\text { Committeereport (SEBI appointed) }\end{array}$ & $\begin{array}{l}\text { SEBI introduction of Clause } 49 \text { in } \\
\text { the Listing agreement; }\end{array}$ & $\begin{array}{l}\text { Revision in Clause } 49 \text { on } \\
\text { recommendation of Narayana Murthy } \\
\text { committee (SEBI appointed) }\end{array}$ & $\begin{array}{l}\text { Revision in Clause } 49 \text { Amendment } \\
\text { base on Dr. J.J.Irani committee }\end{array}$ \\
\hline MARCH, 2012 & MARCH,2013 & OCT. 2014 & OCT., 2018 \\
\hline $\begin{array}{l}\text { Issue of voluntary guideline on } \\
\text { corporate governance (Adi Godrej } \\
\text { committee) }\end{array}$ & $\begin{array}{l}\text { The enactment of the revived } \\
\text { Company ACT }\end{array}$ & $\begin{array}{l}\text { SEBI announces new corporate } \\
\text { governance norms }\end{array}$ & $\begin{array}{l}\text { Separation of role of Non-Executive } \\
\text { Chairman and MD/CEO and others } \\
\text { concerns (Kotak committee report) }\end{array}$ \\
\hline
\end{tabular}

Source:Author.

Table 1 shows a timeline of the Clause 49 reforms. The Kotak committee 2018, reports on recommendations of separating top post company into two different posts of a chairman and CEO/MD.

\section{Kotak Committee}

In June 2017, SEBI established a committee on corporate governance under the chairmanship of Uday Kotak (called the "Kotak Committee"), to improve standards of corporate governance of listed entities in India. Kotak 
committee was formed to review SEBI rules and regulations related to the clause 49 governance issues, and to propose governance laws and reforms. The Committee focuses on the separation of roles of a Chairman and $\mathrm{CEO} / \mathrm{MD}$, and must not be vested in the same person, regarding the top 500 listed companies. Figure 1 shows a timeline of the Kotak committee report.

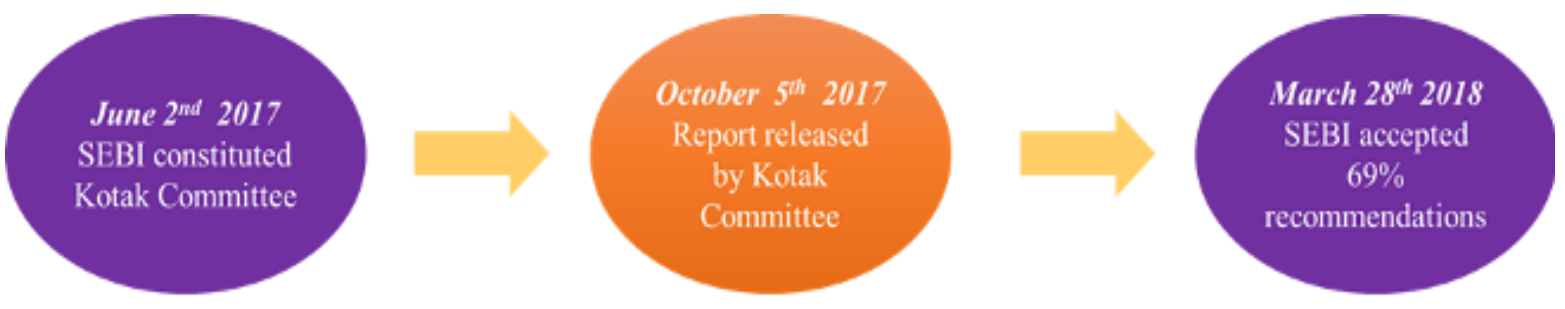

Figure 1: Timeline of the KotakCommittee Report

Source: Shroff and Patnaik(2018).

In March 2018, SEBI had accepted the Uday Kotak-led panel's recommendations to the separation of Chairman and CEO/MD posts for the listed companies. The Kotak Committee's logic was that the leader of the board should not be the leader of the management, thus providing a well-balanced structure of supervision and control.

\section{Current scenario in India}

The SEBI mandated new provision introduced in May 2018 through an amendment to Listing Regulations. This regulatory requirement would have pushed many companies to look at long-term succession planning more effectively, especially in family-run companies. It is based on the amendment outlined on the recommendations of the Committee on Corporate Governance, that was made up by the Kotak Committee. It aimed that these new norms would improve the corporate governance structure of listed companies. Currently, many listed companies, that are family-owned, have merged the roles of chairman and CEO/MD into one. These companies would have to make changes within their board or top leadership positions to comply with the SEBI's new Listing Regulation requirements.

The SEBI through its notification of January 10, 2020, postponed the implementation of the provision mentioned above relating to the separation of roles of a chairman and CEO/MD up until April 01, 2022. It provides additional time for companies to complete and implement their succession planning for these critical positions. The Federation of Indian Chambers of Commerce and Industry (FICCI), and the Confederation of Indian Industry (CII) has welcomed the SEBI's decision to extend its deadline for separating a top position of a company into the positions of a Chairman and a CEO/MD for two years[38]. 
Table2. Chairman \& CEO/MD of top 10 Compliant Companies out of top 500 NSE listed companies

(Unit; Indian Rupee million)

\begin{tabular}{|l|l|l|l|l|c|}
\hline COMPANY NAME & $\begin{array}{c}\text { MARKET } \\
\text { CAP. }\end{array}$ & \multicolumn{1}{|c|}{ CHAIRMAN } & \multicolumn{1}{|c|}{$\begin{array}{c}\text { POSITION ON } \\
\text { CHAIRMAN }\end{array}$} & \multicolumn{1}{|c|}{$\begin{array}{c}\text { CEO/MD NAME/CEO/MD } \\
\text { RELATED }\end{array}$} \\
\hline TCS & $7,95,993$ & Natarajan Chandrasekaran & Chair. non-ED & Rajesh Gopinathan & No \\
\hline HDFC Bank & $6,81,608$ & Shyamala Gopinath & PT,Chair, non-ED & Aditya Tapishwar Puri & No \\
\hline HDFC & $4,01,260$ & Deepak Shntilal Parekh & Chair, non-ED & Renu Sud Kamad & No \\
\hline ICIC Bank & $3,41,184$ & GirishChandra Chaturvedi & PT, Chair, non-ED & Sandeep Bakhshi & No \\
\hline KotakM.Bank & $3,15,036$ & Prakash Krishnaji Apte & PT, Chair, non-ED & Uday Suresh Kotak & No \\
\hline Infosy & $3,04,413$ & Nandan MohanNilekari & Chair,non-ED, PD & Salil Sparekh & No \\
\hline Bajaj Finance & $2,40,125$ & Rahulkumar Bajaj & Chair,non-ED, PD & Rajeev Jain & No \\
\hline Maruti Suzuki India & $2,11,844$ & RavindraChandra Bhargava & Chair, non-ED & Kerichi Ayukawa & No \\
\hline Axis Bank & $2,05,589$ & Rakesh Makhija & PT, Chair, non-ED & Amitabh Chaudhary & No \\
\hline L\& T & $1,82,733$ & Dr. Anil K. Mani Nayik & Chair, non-ED & $\begin{array}{l}\text { Shekharupuram } \\
\text { Subrahmanyan }\end{array}$ & Nangan \\
\hline
\end{tabular}

Note: 1. Market Capital as on 31 March 2019.

2. (Chair. non-ED =Chairman; non-Executive Director); (PT, Chair, non-ED= Part-time, Chairman, non-Executive Director); (Chair, non-ED, PD =Chairman, non-Executive Director, promoter Director)

Source: Economic Time (2020).

The table2 shows top 10 Companies with separated Chairman \& CEO/MD out of top 500 NSE listed companies.Most of them are financial companies, and others are non-financial such as Infosys, Maruti, Suzuki, and L\&T companies. etc.

Table3. Chairman \& CEO/MD non-compliant Companies out of top 500 NSE listed companies

(Unit Indian Rupee million)

\begin{tabular}{|c|c|c|c|c|c|}
\hline COM. NAME & $\begin{array}{c}\text { MARKET } \\
\text { CAP. }\end{array}$ & CHAIRMAN & $\begin{array}{c}\text { CHAIR.ISEXE } \\
\text { CUTIVE }\end{array}$ & $\begin{array}{c}\text { ALSO, } \\
\text { CEO/MD }\end{array}$ & $\begin{array}{c}\text { CHAIR/CEO/MD } \\
\text { RELATED }\end{array}$ \\
\hline Realince Indus. & $9,83,106$ & Mukesh Dhiru Ambani & Yes & Yes & NA \\
\hline H. Unilever & $4,41,070$ & Sanjiv Mehta & Yes & Yes & NA \\
\hline ITC Limitd & $3,03,444$ & Sanjiv Puri & Yes & Yes & NA \\
\hline State bank of india & $3,00,045$ & Rajnish Kumar & Yes & & NO \\
\hline Bharti Airtel & $2,29,578$ & Sunil Bharti Mittal & Yes & & NO \\
\hline ONGC & $1,62,160$ & Shashi Shankar & Yes & Yes & NA \\
\hline Bajaj FinServ. & $1,42,675$ & Rahulkumar Bajaj & Yes & & yes \\
\hline Wipro & $1,39,224$ & Rishad Azim Premji & Yes & & NA \\
\hline Coal India & $1,21,036$ & Anil Kumar Jha & Yes & Yes & NA \\
\hline Indian Oil Crop & $1,18,571$ & Sanjiv Singh & Yes & & NA \\
\hline NTPC & $1,12,897$ & Gurdeep Singh & Yes & Yes & NA \\
\hline BPCL & $1,06,695$ & Duraiswamy Rajkumar & Yes & Yes & NO \\
\hline Power Grid Ind. & 97,988 & Kandikuppa Sreekant & Yes & Yes & NA \\
\hline
\end{tabular}




\begin{tabular}{|l|l|l|l|l|l|}
\hline Bajaj Auto & 93,845 & Rahulkumar Bajaj & Yes & & Yes \\
\hline Adani Ports \& SEZ & 76,294 & Gautam Shantilal Adani & Yes & Yes & Yes \\
\hline
\end{tabular}

Note: Market Capital as on 31 March 2019.

Source: Economic Time (2020).

Table 3 shows the top 15 Companies out of the top 500 NSE listed ones that have not yet separated Chairman \& CEO/MD positions. Most of them are family-owned companies. However, the State Bank of India, Coal India, and Indian Oil Crop companies are Non-family firms.

The table2 and 3 illustrated above showed that the SEBI mandated new regulations have implications for separating and not separating a company's topmost position into the positions of a Chairman and a CEO/MD. Before the SEBI mandated its rules, a few Indian companies had separated their topmost positions into the two different ones mentioned earlier. They are mostly leading financial companies including HDFC Bank, ICIC Bank, HDFC etc. NSE Prime Database (2018) showed that 291 companies (58.2\%) out of the top 500 NSE listed companies by market capitalization would have to have separated Chairman and CEO/MD positions[37]. On the other hand, the same NSE data reveals the current statistics that 162 out of the top 500 companies still have the same single individual holding both the chairman and CEO/MD positions. In 52 companies, the chairman and CEO/MD are related[39]. Overall, the data presented above depicts that family firms are not willing to separate their topmost positions immediately.

\section{Issues and Problems in Role Duality of Chairman and CEO/MD roles in Indian Family firms}

In general, discussions on corporate governance relate issues to 5 major areas: rights and responsibilities of shareholders, role of shareholders, and equitable treatment of shareholders, disclosure and transparency and duties and responsibilities of the board. Other issues include internal controls and independence of the company's auditors, oversight and management risk, oversight of the preparation of the company's financial statement, review of the compensation arrangements for Chairman or CEO and senior executives, the resources made available to directors in carrying out their duties, the way in which individuals are nominated for positions on the board and dividend policy [16].

There are some major problems in corporate governance in relation to family firms. These are:

\section{(1) Lack of Separation of Ownership and Control}

In India, the Listing Requirements are modeled on the Anglo-Saxon model, particularly the Cadbury, Greenbury and Hampel Report UK Codes (Kang, 2001citation by Ponnu et al.[28]. Also, such reports are often modelled on the Kotak Committee of Corporate Governance (KCCG). In relation to the KCCG, the code requires the separation of ownership and control. The separation of two roles is to ensure effective governance and balance of the management's performance[15], [28].If the owner also becomes the manager and chairman, he will not be likely to control the management's activities[21].

However, this separation of ownership and control can hardly be seen in Indian family-owned companies. Most 
family firms are owned and operated by the founder or his/her generations. Referring to figure 3 mentioned above, the chairman and CEO always seem to be family-owned firm's owner. For example, if one looks at the topmost level position of Reliance Industries, it is vivid that Mukesh Ambani is the owner, Chairman of the board, and also the CEO/MD for this corporation. The duality of roles of the owners in the above family-owned companies is not recommended in the KCCG. The KCCG requires a balance of power and authority between the Chairman and CEO/MD, so that no single individual has unconstrained powers of decision.

In summary, one of the main problems of corporate governance in Indian family-owned firms is the lack of separation of ownership and control. Family-run companies do not have a break and may well influence the management board, which may, in turn, influence the policy of dividend and investment[9], and even the approach of remuneration. Audit committees and remuneration committees may not silence the concentration of power in such a situation.

\section{(2) Lack of Transparency and Disclosure}

In Family firms, small investors are often at a great informational disadvantage compared with controlling family shareholders. Normally, the information flows very fast to the family members because of the duality roles of owners in Family firms. It is arguably of greater importance for family companies to effectively implement a policy of continuous public disclosure of relevant operational, financial, and corporate events to enhance transparency for all shareholders. Although the family-run companies fulfil the requirements of the SEBI by publicizing the Audited Report annually, and continuously providing important information to the SEBI, we cannot yet guarantee that there is no insider trading in Family companies. This is because the owners have access to non-public information about the company.

\section{(3) Lack of Good Corporate Management}

After some financial scandal, public companies come under fire from activist shareholders, institutional investors, proxy advisory firms, and regulators. So, separating the chairman and CEO/MDs roles is often front and center to achieve independent leadership on the board. After some of these scandals and scams, the SEBI deeply investigated and also pointed out that the issues related to a company's failure has to do with a single individual holding both topmost executive level positions.

\section{(4) Lack of Corporate Governance awareness and documentation}

Many family firms, mostly start with relatively weak structure and formality, surviving and increasing based on their founders' iron will and creativity. But family businesses also struggle to professionalize and formalize as they expand, like most other ventures. The company gradually becomes complicated enough that "shooting from the hip" becomes increasingly dangerous, as the company's dynamic nature makes running it without structure like attempting to hit a target from a long distance that is continuously and rapidly moving. At that point, what is needed is at least a modicum of formalized company governance or so-called corporate governance. The most significant change at this point in the family firms is that, while there is still a CEO/MDs (usually the founder) who makes all final decisions, there is always an involved Board of Directors, a Family Ownership Group, and a competent management team that helps ensure that the CEO/MDs has the right data to 
make informed decisions.

The Family Mission Statement contains this "correct" material, which, as noted above, should be the guiding light consistent with all strategic and tactical plans being planned. In a properly functioning corporate governance setting, both family and non-family board members and managers must be mindful that they have a fiduciary responsibility to family shareholders to maximize their return in compliance with their wishes. Family firms begin with very little structure and formality, surviving and increasing on the basis of the iron will and imagination of their founders. But family businesses also struggle to professionalize and formalize as they expand, like most other ventures.

\section{(5) Problems of Reforming internal governance system}

Mostly, family firms do not accept the "best practice" or "good corporate governance" solution for matters too immediately without an assert. A counter-intuitive solution may be the best practice for business.

Most family firms are concentrated on one person holding both the roles; a chairman also serves as a CEO/MD of a company. One person holding both roles may trigger a conflict of interest on Executive Compensation, and executive pay decided by a corporate board. For example, the chairman who is also CEO or MD voting on improving his or her own compensation is an apparent conflict of interest. This issue is a hot topic and the right approach to avoid such a high-level executive from involving in an apparent conflict of interest, and to enhance the comprehensive integrity of the company is to separate one topmost position into the two posts as described previously.

\section{(6) Make to Power concentration}

Normally, founding family members appoint a person from within their family in the positions of chairman and CEO to solely preserve the ultimate decision-making powers with them in their corporate structure[28]. A family firm's leader wants to have a concentration of power in the hands of a single individual in India. The family firm promoter group exerts control over its company. However, where a family firm is a first-generation business, a founder is often the chairman and CEO/MD, and thus, wants to self-retain and exercise all corporate powers. This may lead to a business failure of a particular company; the consequence of which, employees have to lose their jobs if any were hired before the failure happened. Hence, the new SEBI principle that there should not be a concentration of power in one hand makes sense. Therefore, the SEBI wants to control the family-owned businesses from collapsing unexpectedly due to power misuse or that a head of a corporate is not able to come up with a mature enough decision, and thus, encourages the concept of separation of power between two posts so that a family-owned business will also have a group of thoughtful people in their highest decision-making level to promote a sustainable business.

\section{The importance of separated Chairman and CEO/MD roles in Corporate Governance performance}

\section{based on lesson from international practices}

Best international practices are that the chairman of the company should not be an executive. The reason is that power gets centralized and concentrated, and there will be no checks and balances[4]. The duality of the Chairman and CEO posts reduces the effectiveness of a board's oversight of management. Comparatively, Firms with a 
duality of roles did not appear to perform better than their counterparts with separate board leaderships, that are based on measures of accountable performances of respective departments.

Most of the family-owned companies' corporate governance issues that have given rise to stakeholder's concern has to do with role duality, also called as a dominant personality phenomenon, in which the CEO/MD is also the chairman of the board. Once, this was a stake of high concern in the United Kingdom. So, the Cadbury committee (1992) of the United Kingdom gave recommendation of Best Practices of Corporate Governance for all its family-owned businesses. Through that recommendation, the corporate governance emphasised on what should be the more precise roles and responsibilities of the chairman and stated that the roles and responsibilities of a chairman should be distinct from that of a CEO/MD for a particular family run firm. If the roles and responsibilities of a chairman and that of a $\mathrm{CEO} / \mathrm{MD}$ are combined into one, then it may create a concern of power misuse for all stakeholders. After this revised has been a significant change in the UK; such as the internal control mechanism is promoted through the one-tier board, composed of executive and non-executive directors, and pushing for investor rights, it has introduced two control tools over the company affairs; internal and external. Every shareholder (possession of a majority or minority holding) concerned about firm performance or reporting issues, would more likely than actively participate in exercising their share rights (sell and buy their shares)[17].

In Malaysia, top management post duality is on the rise, from $8.8 \%$ in 1996 to about $17.9 \%$ in 1999. However, the market has reacted indifferently to the existence of role duality. The results revealed in a research conducted by Rahman \& Haniffa [29] showed that CEO duality reduces monitoring effectiveness. As a result, the overall performance of a company becomes even worse. Thus, the MCCG (Malaysian Code of Corporate Governance) considers that the separation of the two roles is important for better governance of family owned and run businesses[24].

This situation in UK and Malaysia provides a lesson that the separation of the CEO/MD and Chairman's position into two distinct posts may provide the essential power of checks and balances for effective monitoring of corporate governance. So, it is wise if Indian family firms implement the concept of separating their topmost corporate position into two as described by the SEBI.

\section{Suggestion for improvement of effective Board structure after separation}

The rationale behind such recommendation for separation of powers of the chairman and CEO/MD is to keep a better and more balanced governance structure by enabling better and more effective supervision of the management. Hence separation of powers at the topmost level of governance in companies is of paramount importance. So, here are some suggestions for the development of effective Board structure in family firms. These suggestions highlight various advantages that will come from the separation of topmost level corporate power isolated in a single individual into two different posts in Indian family firms. The suggestions are:

(a) requiring a structural advantage for the board to act independently

(b) reducing the excessive concentration of authority in a single individual

(c) clarifying the respective roles of the chairman and CEO/MD and much more diversity and flexibility 
(d) ensuring that board tasks are not neglected by a combined chairman and CEO/MD because of lack of time/capacity

(e) increasing the possibility that the chairman and CEO/MD posts will be assumed by individuals possessing the skills and experience

(f) creating a board environment that is more egalitarian and conducive to debate.

(g) controlling a high level of power concentration.

(h) discontinuing to operate with old traditions and methodologies. Traditional mindsets need to change for the better, and

(i) family firms need to find the right balance between the management board and the family relationships.

With the separation of the role of the Chairman and CEO/MD, the board is expected to function more independently. Separate roles of the Chairman and CEO/MD may likely bring in a balance of power and improving their independence and accountability.

\section{CONCLUSION}

In conclusion, companies with role duality appeared not to perform better than their counterparts with separate board leadership. However, the market reacts indifferently to companies, with or without the duality of roles. The results found in the current survey show that the duality of CEOs reduces the effectiveness of board oversight of management, resulting in poor accountable performances for the entire company. Thus, this implies that the recommendation of the SEBI to have the two roles separated is deemed very significant and must be implemented fully. The separation between the position of Chairman and CEO/MD, which may lead to more independent boards, will provide the essential checks and balances over management's performance. However, most Indian promoter-led companies have a mix of chairman and managing director posts. The promoter states that the committee does not recommend associating the two posts and hopes that the order will be postponed for a couple of years.

Finally, in case Indian firms sincerely feel that the separation of posts is not a good governance measure and not value accretive, they must spell out their doubts clearly to the regulatory agencies and have a lucrative argument that could outweigh the SEBI's principle. In India, even though the provision was made mandatory, most companies have adopted a wait and see strategy until the end of the SEBI's deadline, hoping that the law would be scrapped. Also, Indian promoters are not willing to easily transfer corporate power to the next generation. It may need careful planning for the transformation. If implemented such a power separation properly, the board will get flexibility to operate more freely, and is expected to bring in a balance of power and reinforcement of accountability. This separation has been approved in various jurisdictions abroad as part of sound governance principles. 


\section{REFERENCE}

[1] Alpay, G., Bodur, M., Yılmaz, C., Çetinkaya, S., \& Arıkan, L. (2008). Performance implications of institutionalization process in family-owned businesses: Evidence from an emerging economy. Journal of World Business, 43(4), 435-448. doi: 10.1016/j.jwb.2008.03.006

[2] Anderson, R. C., \& Reeb, D. M. (2003). Founding-family ownership, corporate diversification, and firm leverage. The Journal of Law and Economics, 46(2), 653-684.

[3] Astrachan, J. H., \& Shanker, M. C. (2003). Family businesses' contribution to the US economy: A closer look. Family business review, 16(3), 211-219.

[4] Bansal, S. (2020). Charter for the Chair: A Discussion on the Mandate of a Separate Chairman for Boards and the Expected Role-Play. Available at SSRN 3538977.

[5] Black, B. S., \& Khanna, V. S. (2007). Can corporate governance reforms increase firm market values? Event study evidence from India. Journal of Empirical Legal Studies, 4(4), 749-796.

[6] Burkart, M., Panunzi, F., \& Shleifer, A. (2003). Family firms. The journal of finance, 58(5), 2167-2201.

[7] Chakrabarti, R., Megginson, W., \& Yadav, P. K. (2008). Corporate governance in India. Journal of Applied Corporate Finance, 20(1), 59-72.

[8] Chittoor, R., \& Das, R. (2007). Professionalization of management and succession performance-A vital linkage. Family Business Review, 20(1), 65-79.

[9] Claessens, S., Djankov, S., \& Lang, L. H. (2000). The separation of ownership and control in East Asian corporations. Journal of financial Economics, 58(1-2), 81-112.

[10] Corey Stern(2015), 'The 21 biggest family-owned businesses in the world' Business Insider, 14 July, 2015, Available at: https://www.businessinsider.com/the-worlds-21-biggest-family-owned-businesses-2015-7 (27 July,2020 Accessed).

[11] Dave, M., Gehlot, K., \& Gupta, M. (2012). Application of Clause 49 By Indian Listed Companies. Ahmedabad Chief Editor, 43(1), $78-89$.

[12] Dharmapala, D., \& Khanna, V. (2013). Corporate governance, enforcement, and firm value: evidence from India. The Journal of Law, Economics, \& Organization, 29(5), 1056-1084.

[13] Dinh, T.Q. and Calabrò, A. (2019), Asian Family Firms through Corporate Governance and Institutions: A Systematic Review of the Literature and Agenda for Future Research. International Journal of Management Reviews, 21: 50-75. https://doi.org/10.1111/ijmr.12176.

[14] Faccio, M., \& Lang, L. H. (2002). The ultimate ownership of Western European corporations. Journal of financial economics, 65(3), $365-395$.

[15] Haniffa, R. M., \& Cooke, T. E. (2002). Culture, corporate governance and disclosure in Malaysian corporations. Abacus, 38(3), 317-349.

[16] Jaffer, M. J., \& Sohail, S. B. (2007). Corporate governance issues in family-owned enterprises. Economic Reform Feature Service.

[17] Kakabadse, N. K., \& Kakabadse, A. P. (2007). Chairman of the board: demographics effects on role pursuit. Journal of Management Development.

[18] Kamesam, V. (2006). Corporate best practices: Recommendations for directors. IRDA Journal, 26-29. 
[19] Kiong, T. C. (2005). Feuds and legacies: Conflict and inheritance in Chinese family businesses. International Sociology, 20(1), 45-70.

[20] La Porta, R., Lopez-de-Silanes, F., \& Shleifer, A. (1999). Corporate ownership around the world. Journal of Finance, 54(2), $471-517$.

[21] Lai, Dominic Yew Hock (2007). Leadership and ethnicity in public companies in Malaysia. Journal of Law and Governance, 2(2).

[22] Lange, H., \& Sahu, C. (2008). Board structure and size: The impact of changes to Clause 49 in India.

[23] Loh, L., Thomas, T., \& Wang, Y. (2017). Sustainability reporting and firm value: Evidence from Singapore-listed companies. Sustainability, 9(11), 2112.

[24] Malaysian Code of Corporate Governance (2000). Securities Commission, Finance Committee on Corporate Governance, Kuala Lumpur. Available at: https://www.sc.com.my/api/documentms/download.ashx?id=70a5568b-1937-4d2b-8cbf-3aefed112c0a (Accessed, 20 July 2020)

[25] Merchant, P., Kumar, A., \& Mallik, D. (2017). The Role of Quality of Relations in Succession Planning of Family Businesses in India. Journal of Asian Finance, Economics and Business, 4(3), 45-56.

[26] OECD. (1999). Principles of Corporate Governance. OECD Publications. Retrieved from https://www.oecd.org/officialdocuments/publicdisplaydocumentpdf/?cote=C/MIN(99)6\&docLanguage=En

[27] Pande, S., \& Kaushik, K. (2012). Study on the state of corporate governance in India. New Delhi: Indian Institute of Corporate Affairs.

[28] Ponnu, C. H., Lee, C. K., Tan, G., Khor, T. H., \& Leong, A. (2009). Corporate Governance in Family Business -A Malaysian Case study, Corporate Ownership and Control, 6(4), 135-147.

[29] Rahman, R. A., \& Haniffa, R. M. (2005). The effect of role duality on corporate performance in Malaysia. Corporate ownership and control, 2(2), 40-47.

[30] Saravanan, P., Srikanth, M., \& Avabruth, S. M. (2017). Compensation of top brass, corporate governance and performance of the Indian family firms-an empirical study. Social Responsibility Journal.

[31] Sen, A. (2011). Corporate governance in India: Clause 49 of the listing agreement. Gupta, SC 275 Gupta, Sonia 423 Gupta, Swati 353 Gupta, Vishal 569, 238.

[32] Shen, N. (2018) Family business, transgenerational succession and diversification strategy: Implication from a dynamic socioemotional wealth model. Cross Cultural \& Strategic Management, Vol. 25 No. 4, pp. 628-641, https://doi.org/10.1108/CCSM-06-2017-0074

[33] Shleifer, A., \& Vishny, R. W. (1986). Large shareholders and corporate control. Journal of political economy, 94(3, Part 1), 461-488.

[34] Shroff, R., Patnaik, T., \& Keshari, K. (2018). India’s Tough New Corporate Governance Regime - Impact on Promoters. Retrieved from Private Client website: https://privateclient.cyrilamarchandblogs. com/2018/04/indias-tough-new-corporate-governance-regime-impact-promoters/

[35] Teixeira, S., Veiga, P. M., Figueiredo, R., Fernandes, C., Ferreira, J. J., \& Raposo, M. (2019). A systematic literature review on family business: insights from an Asian context. Journal of Family Business Management.

[36] Thapar, M., \& Sharma, A. (2017). Corporate governance in India: An analysis. Economic and Social Development: Book of Proceedings, 312. 
[37] The Economic Time. (2018). Sebi norms: 291 listed firms need to split CMD post, Jul 22,2018 [Online]. Available at: https://economictimes.indiatimes.com/markets/stocks/news/sebi-norms-291-listed-firms-need-to-split-cmd-post/articleshow/6509076 6.cms (Accessed: 20 May 2020).

[38] The Economic Time (2020). Sebi defers deadline by 2 years to split chairman \& MD post, Jan 13, 2020 [Online]. Available at: https://economictimes.indiatimes.com/markets/stocks/news/sebi-gives-more-time-to-implement-cmd-post-rules/articleshow/7322815 7.cms (Accessed:20 May 2020).

[39] Upadhyay, J.P. (2020). India Inc breathes easy, gets two years to split CMD position. Mint. Retrieved from https://www.livemint.com/companies/news/india-inc-gets-a-breather-from-sebi-gets-two-years-to-split-cmd-post-11578925148320.ht ml (Accessed: 20 May 2020). 